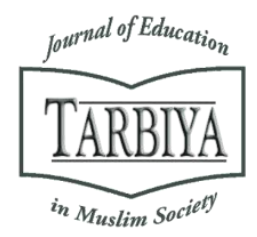

Available online at TARBIYA: Journal of Education in Muslim Society Website:

http://journal.uinjkt.ac.id/index.php/tarbiya

TARBIYA: Journal of Education in Muslim Society, 5(2), 2018, 126-134

\title{
SCHOOL OF MASTER TEACHER (SMT) TRAINING: DEVELOPING TEACHERS' PEDAGOGIC COMPETENCE
}

\author{
Jejen Musfah, Desita Erviani \\ Syarif Hidayatullah State Islamic University of Jakarta, Indonesia \\ E-mail: jejen@uinjkt.ac.id
}

\author{
Received: $16^{\text {th }}$ August 2018; Revised: $15^{\text {th }}$ November 2018; Accepted: $28^{\text {th }}$ December 2018
}

\section{Abstract}

This study aimed at analyzing School of Master Teacher (SMT) training in developing teacher's pedagogic competence. This study applied a qualitative approach within the framework of case study research. The data was collected through documentation, observation, and interviews. The results showed that SMT training consisted of lectures, social projects, and Classroom Action Research (CAR). Secondly, the training was able to improve teachers' pedagogic competence with excellent results. 22 of 33 teachers showed accomplished pedagogic competence. While, 9 teachers performed a very good level of the competence in their instruction, 1 teacher gained a medium level, and only 1 teacher received a poor mark.

Keywords: pedagogic competence; SMT training; Classroom Action Research (CAR)

\section{Abstrak}

Penelitian ini bertujuan untuk menganalisis pelatihan School of Master Teacher (SMT) dalam mengembangkan kompetensi pedagogik guru. Penelitian ini menerapkan pendekatan kualitatif dalam kerangka penelitian studi kasus. Data dikumpulkan melalui dokumentasi, observasi, dan wawancara. Hasil penelitian menunjukkan bahwa pelatihan SMT terdiri dari ceramah, proyek sosial, dan Penelitian Tindakan Kelas (PTK). Kedua, pelatihan ini mampu meningkatkan kompetensi pedagogik guru dengan hasil yang sangat baik. 22 dari 33 guru menunjukkan kompetensi pedagogik yang baik. Sementara, 9 guru menunjukkan tingkat kompetensi yang sangat baik dalam pengajaran mereka, 1 guru memperoleh tingkat sedang, dan hanya 1 guru yang mendapat nilai buruk.

Kata kunci: kompetensi pedagogic; pelatihan SMT; Penelitian Tindakan Kelas (PTK)

How to Cite : Musfah, J., Erviani, D. (2018). School of Master Teacher (SMT) Training: Developing Teachers' Pedagogic Competence. TARBIYA: Journal of Education in Muslim Society, 5(2), 126-134.

doi:10.15408/tjems.v5i2.10622.

Permalink/DOI: http://dx.doi.org/10.15408/tjems.v5i2.10622

TARBIYA: Journal of Education in Muslim Society, p-ISSN: 2356-1416, e-ISSN: 2442-9848 


\section{Introduction}

The essence of education is the learning process. The quality learning is the key factor in shaping the nation's good generation with excellent intellectual and spiritual potential. The quality of learning is mostly influenced by the quality of teachers. According to Barnawi and Arifin (2012), quality learning can only be facilitated by teachers with good skills and high motivation.

Teachers are the focal points in teaching learning process as they who directly interact with students in the classrooms (Fathurrohman \& Suryana, 2012). It is no exaggeration to say that the future of society, nation and state is determined by them (Sumarso, 2016). The enhancement of education should therefore place a greater emphasis on teachers' quality.

Being a teacher requires good competence. According to Novauli (2012), teachers' competence are knowledge, skills and attitudes which are indicated by intelligent and responsible behavior. The Constitution of the Republic of Indonesia Number 14 in 2005 on Teachers and Lecturers stated, "Teacher competence include pedagogic, personality, social, and professional competence obtained through professional education." According to Alfia (2014), pedagogic competence is a competence that typically characterizes and distinguishes the profession of teachers from other professions.

Regulation of the Minister of National Education Number 35 in 2010 on Technical Guidelines for Implementing the Functional Position of Teachers and their Credit Scores, pedagogic competence consists of seven competencies, namely (1) mastering the characteristics of students, (2) educational principles and theories of learning, (3) curriculum development, (4) educational activities, (5) students' potential development,
(6) communication with students, (7) assessment and evaluation.

In 2015, the Teacher Competence Test ( $U_{j i}$ Kompetensi Guru/UKG) showed disappointing results. The national average of $U K G$ is 53.02, while, the government targeted the average score at 55. The average of teachers' pedagogic competence was 48.94, and the score of professional competence was 54.77 (Musfah, 2011). Teacher competence, especially the pedagogic one, still needs a lot of attention. The School of Master Teacher (SMT) training of Indonesian Teachers School (Sekolah Guru Indonesia/SGI) focuses on improving teachers' pedagogical competence. Instructional competence is influenced by many variables (Singh, 2010). Competence is a process, not an endpoint for novice teachers, but as a part of the process of becoming a professional teacher (Arnesen, 2010).

\section{Method}

In collecting the data, the researchers did observation, interviews, and documentation. They applied the participatory observation method. The researchers took part in the SGI SMT training as facilitators whose functions as the instructor, speaker, coach, and treasurer of the training program in Bojonggede, Bogor. The data observed directly in the field were (1) the activities of teachers participating in the training, from the beginning of the meeting to the end, and (2) learning methods conducted by facilitators in the class.

The sources of information (informants) were the chairman of SGI; a SMT facilitator, namely Ayu; a SMT Facilitator in Parung; the researchers themselves as SMT facilitators in Bojonggede; and 4 SMT teachers in Bogor District; the principal and 2 students of the Elementary School Kedung Waringin 04. The researchers also collected some documents such 
as the profile of SMT, lesson plans (Rencana Pelaksanaan Pembelajaran/RPP), observational data of teaching learning process, and participants' CSI (Customer Satisfaction Index) data of the training as the supporting data. The study was conducted in April to November 2017.

\section{Results and Discussion}

The SMT training was a training aimed at helping teachers to develop their pedagogical competence. Kaswan (2013) stated that training is a process of increasing knowledge, improving skills, and changing attitudes so that they can work more effectively. Teacher professionalism is influenced by regulations, school classrooms and communities, and teacher education curricula (Brundett \& Silcock, 2002).

Pedagogic competence is needed by teachers because they face students who not only demand the instruction, but also personal development (Irwantoro \& Suryana, 2016). The curriculum of SMT training was designed more practical with the proportion of $80 \%$ practice and $20 \%$ theories. The SMT program was held for 3 months ( \pm 90 hours), every Sunday. The materials obtained on Sunday were immediately practiced on Monday to Saturday in teaching learning activities.

The SMT program consisted of 12 face-toface meetings starting from Studium General (SG), Military Super Camp (MSC), (lecture) classes for 6 meetings (Effective Class 1, Reflective Class 1, Effective Class 2, Creative Class 1, Creative Class 2, and Reflective Class 2), social projects, summative tests, Classroom Action Research (CAR), and graduation.

The development of teacher's pedagogic competence could be elaborated through the following indicators:

\section{Recognition of students' characteristics}

According to Atwi (2014), the initial characteristics are the characteristics of students before participating in learning. These characteristics affect the achievement of learning objectives. The SMT training provided the materials about mastering the characteristics of students in the course of Effective Class. Learning style is one of the learning characteristics related to absorbing, processing, and conveying the information (Kartika, 2014, p. 3). Students' learning styles are varied. Some students learn something by seeing others do it, some just by listening, and some by being directly involved - i.e. Visual, Auditory, and Kinesthetic (VAK). The teacher should notice well the characteristics of students so they can determine learning strategies.

This material was presented in the first session of the Effective Class on the first day. The facilitator gave an explanation of the types and characteristics of learning styles and identification of friends' learning styles. Moreover, within the course, it was also explained that the goal after participating in this learning activity, the participants could be able to identify the learning styles of their friends.

Based on the teaching observation conducted by the researchers on Maryanti with her approximately 38 students (January 25, 2017), the pedagogic competence had been applied well. She taught the Islamic subject in the $2^{\text {nd }}$ Grade with a variety of innovative learning models.

In innovative learning, students involve themselves actively and are not only objects (Shoimin, 2014). Maryanti's methods are very diverse, including contextual learning method, singing, discussing, questioning-answering (QA), lecturing, and doing make a match. The students were very enthusiastic in following the instruction delivered by their teacher. 


\section{Mastery of educational principles and} theories

SMT training provided the material in the second session of the Effective Class on the first day. The facilitator delivered the explanations of what learning is, how good learning is, the difference between active and passive learning, and an understanding of the differences of the four instructional terms, namely approaches, methods, strategies, and learning techniques. Then, the facilitator gave examples of active learning models and practiced them in the class. Pribadi (2016) stated that training instructor not only play the role of delivering materials, but also act as facilitator that well facilitates the ongoing learning process in the training programs.

Learning activities in the classroom were run by various learning models and methods, including contextual learning, songs, discussion, question and answer, lectures, and make a match. Maryanti did a good learning process. For example, she used the singing method by giving the sticks to students and sang together with them. When the teacher and students stopped singing, the students did what the teacher instructed. The learning process was carried out through various ways. The students felt enthusiastic, enjoyed the learning activities delivered, and if they can answer questions, they were given a reward, for example, in the form of appreciative applause. Shoimin (2014) explained that teachers facilitate students to learn so that they are more free to learn. Maryanti can thus be said to be an effective teacher.

The researchers also observed Mudrikah (01/25/17, 10:30 a.m.). He delivered various methods including lecturing, storytelling, question and answer, and demonstration in one lesson. What Mudrikah did was ideal enough since more than 3 methods were used at one time. So, the students are very facilitated and enthusiastic in listening to the teacher.

\section{Curriculum development}

The teacher must make a lesson plan (Rencana Pelaksanaan Pembelajaran/RPP) before teaching learning activities. According to Al-Tabany (2015), RPP contains learning objectives, teaching materials, teaching methods, learning resources, and assessment of learning outcomes. A lesson plan makes learning achieve maximum results (Rusman, 2015). RPP is a tool that can help teachers be more effective in carrying out their duties and functions (Syarif, 2015).

Before making the plan, participants were given an understanding of its functions, objectives and components, explanation of core (Kompetensi Inti/KI) and basic competencies (Kompetensi Dasar /KD), the principles of the preparation of special instructional objectives (Tujuan Intruksional Khusus/TIK), and the maximization of cognitive, affective, psychomotor aspects. Having the teachers understood in the principle of TIK based on the rule of Audience, Behavior, Condition, and Degree (ABCD), they then designed and developed a lesson plan in the second session.

The formulation of the material should be in accordance with the learning objectives, that is, formulated in sentences using operational verbs (Kata Kerja Operasional/KKO) and complete elements known as ABCD (Sumantri, 2015). Finally, the teacher explained and discussed the RPP by giving responses/feedback. The teacher has been able to prepare the lesson plan well.

\section{Educative and dialogical learning activities}

According to Ladjid (2005), teaching and learning is a term that implies the activities of interaction between the teacher and students to achieve the stated goals. Teachers should be able to manage the classroom as a learning environment which is an aspect of the school 
environment that needs to be organized (Badrudin, 2014).

SMT training provided the materials for class management as well. Class management is an effort to empower existing class potentials optimally to support the educational interaction process to attain instructional goals (Djamarah, 2000). According to Jones (2012), effective classroom management facilitates learning by fulfilling the academic needs of students, both as a class and individuals.

Learning media was likewise explained in the course of Creative Class. Learning media is a tool that can be used by educators in helping their educational duties (Mulyanta, 2009). Participants were given an explanation ranging from the understanding, principles, functions, classification, various types, analysis of the use and planning, and also (direct practice) the making of learning media. The purpose of this session was the participants could be able to organize the class and make the classroom display well. The participants of this training also carried out a social project, i.e. sharing the materials that had been obtained during the training to their colleagues in their schools.

\section{Students' potential development}

Irwantoro and Suryana (2016) argued that students should be directed to find out themselves, solve their problems and develop the meaning of the lessons with the reality of their own lives. Learning atmosphere must be challenging, fun and motivating as well as train them more to express, explore, argue, experiment, create, innovate and collaborate.

SMT training started from analyzing the characteristics of students. It was conducted by giving the students a questionnaire that led to students' learning styles so that the teacher would be able to determine the appropriate learning strategies. Appreciation given by the teacher to students can make students more motivated to release all their potential in learning process (Irwantoro \& Suryana, 2016).

Maryanti (01/25/17) developed the potential of students well. The teacher designed and implemented learning activities in accordance with the learning patterns of each student. The instructional method embraced all students' learning styles in order to develop, think critically, and actively involved in the learning process in the classroom.

Dinar also carried out teaching learning activities that might boost students' potential by paying attention to their needs and learning styles in processing and absorbing the information. Many methods were applied in one class such as initial apperception, songs, make a match, and contextual learning, for instance, in learning the material on Ulul 'Azmi apostles (five most respected prophets in Islam, i.e. Noah, Abraham, Moses, Jesus and Muhammad pbh.), made the students very interactive.

They could understand the lesson easily and felt happy to be involved in the learning process. When the child is happy and comfortable with the learning done, then he will easily absorb the information conveyed by his teacher. Materials on learning models and designs delivered in the Effective Class significantly assisted the teachers in developing their students' potential.

\section{Communication with students}

Maryanti (January 25, 2017) could deliver the material effectively so that two-way communication was established, and the teacher provided feedback on students' understanding. Effective communication is a reciprocal relationship between teachers and students (Syarif, 2015).

The teacher brought pictures and presented them well to the students so their curiosity was awakened. Maryanti had high creativity in the 
learning process she carried out. Teachers must have creativity to support their teaching (Shoimin, 2014). Students were given the opportunity to ask questions about anything and when they had difficulty in completing their tasks, and the teacher provided guidance so the students know how to ask. Teachers are mediators (Badrudin, 2014).

\section{Assessment and evaluation}

Rusman (2015) asserted that authentic assessment is a variety of assessment methods that allow students to demonstrate their ability to complete tasks and solve problems. Authentic assessment should be able to describe what attitudes, skills and knowledge have been obtained by the students, how they apply their knowledge, and in what ways they have been able to apply their learning acquisition.

SMT training provided the materials on authentic assessment. The purpose of this Reflective Class was the participants can make an assessment of three domains, namely cognitive, affective and psychomotor assessments. The teacher utilize the inputs from students and reflect on them to improve further learning. The teacher wrote them in learning journals and designs. Syarif (2015) posited that the results of evaluation can be used as feedback so that they can be used as a basis for policy making in improving the quality of learning.

SMT training also gave the material on CAR proposals in session 1 and 2 of the Reflective Class. The teachers observed the problems they faced in their classroom, and then they reflected on them to design a CAR proposal until it could be published in the proceedings of the learning journal (CAR journal). Before being published, their proposals were tested and assessed by the facilitators. Having tested, the teachers then revised, printed and published their CAR proposals in the proceedings. In the first session of Reflective Class, they learned about definitions, models, benefits of CAR, and in the second session, they designed and developed CAR proposals.

In SMT training, there were three main agenda and focuses in improving the pedagogical competence of teachers in Bogor Regency, namely lecture, social project, and Classroom Action Research (CAR). The details were as follows:

\section{Lecture}

Lecture was a learning process using twoway communication between facilitators and participants regarding the instructional materials in Effective, Creative and Reflective Classes. According to Kaswan (2016), training materials must be meaningful. Training materials must be relevant to the realization of the training objectives (Musfah, 2012). The facilitators also provided materials with very good methods.

The methods used by the facilitators were adequate enough. This is inseparable from their role in teaching the course materials, in which the learning methods comprised $80 \%$ practice and only $20 \%$ for theories, the materials therefore can simply be applied by the teachers in teaching their students.

In Parung, the score obtained was $97 \%$ and in Bojonggede was up to $98 \%$. Participants were very satisfied with the way the facilitators delivered the lectures. Based on the observation during the training, the facilitators applied fun methods, such as giving interesting stimuli, providing miscellaneous games and instructional techniques that used apperceptions relevant to the materials, and demonstrating learning media, so that the trainees were not bored and excited in attending the lectures. 


\section{Social project}

The social project was a part of the SMT training series. This social project at SMT of SGI XXIV gave a more emphasis on the socially educational project. The teachers were able to conduct educative and dialogical teaching learning activities and to communicate them well to the participants.

\section{Classroom Action Research (CAR)}

In the implementation of SMT training, having learned CAR materials in Reflective Class, the teachers conducted CAR in his teaching activities. Then, they discussed their research proposals with the facilitators prior to their CAR were tested and presented. After the proposals were examined by the examiners, they revised their proposals. These CAR works were furthermore published into the proceedings of learning journal.

This was very helpful for the teachers in implementing reflective action in teaching learning process. The teachers could notice their instructional weaknesses. They therefore fixed the weaknesses to improve the quality of learning, so the students could easily absorb the lessons and their learning outcomes increase. Students can learn from mistakes, and teachers must take full advantage of that opportunity in the classroom (Wuttke \& Seifried, 2017).

\section{Pedagogic Competence Development}

The development of teachers' pedagogic competence in Bogor Regency can be seen through teaching observation activities. Teaching observation in SMT training was held twice in three months of the training. This observation aimed to see how the teachers developed their teaching after following the lectures. The following were the scores of teaching observation before and after attending the SMT training.
The average score in phase lof the teaching observation, before getting the training, was 72 . What the facilitators had delivered during the lecture was put into practical use. The teachers were able to apply their pedagogical competence in the classroom learning. During the first observation, after carrying out teaching activities, the teachers and facilitators reflected on what was not good and needed to be improved, and what good that must be maintained.

In the second phase of teaching observation (after attending the training), there was a significant increase, rose by 82 . The teachers applied the training materials very well. There was a $10 \%$ increase in their pedagogic competence.

22 out of 33 teachers who had attended SMT training could improve their pedagogical competencies with excellent skills and get the mark, Accomplished. Moreover, 9 teachers received Proficient or were very good at applying the pedagogic competence in their teaching. 1 teacher got the mark, Developing, or good enough and only 1 teacher obtained Need Improving. From the total number of teachers attended the training, 31 teachers or $94 \%$ of them were able to carry out their pedagogical competence well. SMT training had thus an indispensable contribution in developing the pedagogic competence of teachers in Bogor Regency.

\section{Conclusions}

First, the SMT training comprised lectures, social project, and Classroom Action Research (CAR). Second, the SMT training was able to improve the pedagogic competence of teachers with satisfactory results. A total of 22 from 33 teachers received excellent marks; 9 teachers performed very well in applying pedagogic competence; 1 teacher got a good mark; and another teacher needed more improvement. 
Some suggestions can therefore be made. Firstly, the training graduates performed the pedagogic competence very well, so that the $S G I$ program should be better maintained and the number of teachers attending the training ought to be increased. Second, the teachers should consistently practice the knowledge and skills obtained through the training, and share them with the others. Third, schools are to provide opportunities for teachers to take part in both paid and unpaid training as an event to upgrade themselves. And, finally, the local governments should provide similar training in their regions, especially those that have never held the training.

\section{References}

Alfia, A. N. (2014). Meningkatkan Kompetensi Pedagogik Guru di SD Yayasan Mutiara Gambut. Jurnal Administrasi Pendidikan Jurusan Administrasi Pendidikan FIP UNP, $2(1)$.

Al-Tabany, T. I. B. (2015). Mendesain Model Pembelajaran Inovatif, Progresif dan Kontekstual: Konsep, Landasan dan Implementasinya pada Kurikulum 2013. Jakarta: Prenadamedia Group.

Arnesen, A. L. (2010). Policies and Practices for Teaching Sociocultural Diversity. French: Council of Europe Publishing.

Atwi, M. S. (2014). Desain Instruksional Modern: Panduan Para Pengajar Inovator Pendidikan. Jakarta: Erlangga.

Badrudin. (2014). Manajemen Peserta Didik. Jakarta: Indeks Permata Puri Media.

Barnawi, \& Mohammad, A. (2012). Instrumen Pembinaan, Peningkatan, dan Penilaian Kinerja Guru Profesional. Jogjakarta: ArRuzz Media.

Brundett, M., \& Silcock, P. (2002). Achieving Competence, Success and Excellence in Teaching. London: Routledge Palmer.
Djamarah, S. B. (2002). Guru dan Anak Didik dalam Interaksi Edukatif. Jakarta: Rhineka Cipta.

Fathurrohman, P., \& Suryana, A. A. (2012). Guru Profesional. Bandung: Refika Aditama.

Irwantoro, N., \& Suryana, Y. (2016). Kompetensi Pedagogik. Surabaya: Genta Group Production.

Jones, V., \& Jones, L. (2012). Manajemen Kelas Komprehensif. Jakarta: Kencana.

Kartika, A. S. (2014). Analisis Karakteristik Gaya Belajar VAK (Visual, Auditori, Kinestetik) Mahasiswa Pendidikan Informatika Angkatan 2014. Jurnal Ilmiah Edutic Universitas Trunojoyo, 1 (1).

Kaswan. (2016). Pelatihan dan Pengembangan untuk Meningkatkan Kinerja SDM. Bandung: Alfabeta.

Ladjid, H. (2005). Pengembangan Kurikulum menuju Kurikulum Berbasis Kompetensi. Ciputat: Ciputat Press Group.

Mulyanta, M. L. (2009). Tutorial Membangun Multimedia Interaktif Media Pembelajaran. Yogyakarta: Universitas Atma Jaya Yogyakarta.

Musfah, J. (2011). Peningkatan Kompetensi Guru: Melalui Pelatihan dan Sumber Belajar Teori dan Praktik. Jakarta: Kencana Prenada Media Group.

Novauli, F. (2012). Pengaruh Kompetensi Guru terhadap Peningkatan Prestasi Belajar pada SMP Negeri di Kota Banda Aceh. Jurnal Pencerahan Majelis Pendidikan Daerah Aceh, 6 (1).

Pribadi, B. A. (2016). Desain dan Pengembangan Program Pelatihan Berbasis Kompetensi Implementasi Model ADDIE. Jakarta: Prenada Media Group.

Rusman. (2015). Pembelajaran Tematik Terpadu: Teori, Praktik dan Penilaian. Jakarta: Rajawali Pers. 
Shoimin, A. (2014). 68 Model Pembelajaran Inovatif dalam Kurikulum 2013. Jogjakarta: Ar-Ruzz Media.

Singh, V. K. (2010). Teaching Competency of Primary School Teachers. India: Gyan Publishing House.

Sumantri, M. S. (2015). Strategi Pembelajaran: Teori dan Praktik di Tingkat Pendidikan Dasar. Jakarta: Raja Grafindo Persada.
Sumarso. (2016). Guru Pembelajar: Upaya untuk Meningkatkan Kompetensi Guru (Antara Harapan dan Tantangan Masa Depan. Pandeglang: Dinas Pendidikan dan Kebudayaan Kabupaten Pandeglang.

Wuttke, E., \& Seifried, J. (Eds.). (2017). Professional Error Competence of Preservice Teachers: Evaluation and Support. Switzerland: Springer. 